\title{
'n Vertelkundige ontleding van Psalm 105 met besondere verwysing na die funksie van vertelde ruimte
}

\author{
G C Lindeque \& A P B Breytenbach \\ Universiteit van Pretoria
}

\begin{abstract}
A narrative analysis of Psalm 105 with special reference to the function of narrated space

The purpose of this article is to illustrate the value of a narrative analysis of Psalm 105. Because space plays a very important role in the Psalm, the special function of narrated space is investigated. From the results of the narrative analysis some theological lines as well as a possible date for the Psalm are given in the conclusion.
\end{abstract}

\section{BEGRONDING}

In die verlede is daar in die eksegese van Psalm 105 hoofsaaklik van die historieskritiese benadering gebruik gemaak (vgl Weiser 1962:671-676). Navorsers soos Ceresco $(1978,1983)$, Hill $(1983)$ en Clifford (1979) het in hulle ondersoeke van die psalm veral die poëtiese kwaliteite daarvan aangetoon. Holm-Nielsen (1977) en Fensham (1981) beklemtoon weer die historiese tradisies in die psalm. In hierdie artikel word daar van die standpunt uitgegaan dat Psalm 105 'n verhalende teks is. Dit beteken dat die psalm ook vertelkundig ondersoek kan word.

Die hoofdoel van hierdie artikel is om die besondere waarde van 'n vertelkundige ontleding van Psalm 105 aan te toon. Aangesien ruimte so 'n belangrike rol in die psalm speel, is dit 'n verdere doelstelling om die besondere funksie van vertelde ruimte in die vertelling na te gaan. Ten slotte kan daar op grond van die vertelkundige ontleding 'n paar teologiese lyne getrek word en afleidings ten opsigte van die ontstaanstyd en -plek van die psalm gemaak word.

- Ingedicn en aanvaar as deel van die vereistes vir die MDiv-graad, Fakulteit Teologie (Afd A), Universiteit van Pretoria, onder leiding van prof dr A P B Breytenbach. 


\section{2. 'N VERTEL KUNDIGE ONTLEDING VAN PSALM 105}

\subsection{Wat is ' $\mathrm{n}$ vertelling?}

Daar is vandag heelwat literatuurteoretiese werke beskikbaar wat oor die narratologie handel (bv Genette 1980; Bal 1980; Prince 1982). Brink (1987) se werk bied nie 'n nuwe benadering aan nie, maar is ' $n$ samevatting van die huidige stand van sake in die narratologie en wil aan die leser "n stel gereedskap aanbied waarmee die verhaalkuns as vertelkunde gehanteer kan word' (Brink 1987:9). Brink het 'n funksionele uitgangspunt en daarby bied sy werk die moontlikheid van 'n eenvormige Afrikaanse terminologie. Daarom berus die metode wat in hierdie artikel gevolg word, in hoofsaak op sy benadering van die vertelkunde (alhoewel daar ruimskoots van ander literatuurteoretici se insigte gebruik gemaak word).

In aansluiting by Genette onderskei Brink (1987:39) drie vlakke in die ontleding van 'n verhaal, naamlik die vertelteks, die storie en die vertelproses. Met 'vertelteks' word bedoel 'dit...wat op die papier voor my staan, waarby mens nie net die opeenvolging van sinne in gedagte het nie, maar...die organisasie van die verhaal...' (Brink 1987:39). Die storie 'verteenwoordig die leser se konstruksie van 'n gegewe met ' $n$ begin, ' $n$ middel en 'n einde, opgebou volgens die logiese, chronologiese en kousale patrone wat daardie leser uit sy eie belewenis van die wêreld ken' (Brink 1987:40). Onder 'vertelproses' word verstaan 'die hele kompleks waardeur 'n vertelteks tot stand kom en weer gedekodeer word' (Brink 1987:40).

Die volgende definisie van 'n verhaal kan dus as uitgangspunt geneem word: 'In 'n verhaal word daar in die vorm van 'n [prosa]taalteks 'n storie vertel deur iemand, aan iemand, in sekere omstandighede' (Brink 1987:40).

\subsection{Vertelteks}

\subsubsection{Struktuur}

Alhoewel 'n volledige struktuuranalise van Psalm 105 hier geplaas behoort te word, laat die beskikbare ruimte vir hierdie studie dit nie toe nie en word daar met die volgende opmerkings volstaan:

- Die begin en einde van die teks is vasgestel vanweë die feit dat die psalm as 'n lied, dit wil sê 'n afgeslote eenheid gefunksioneer het.

- Op grond van die styl en inhoud kan die teks in die volgende eenhede (paragrawe) onderverdeel word: vers 1-6, 7-11, 12-15, 16-23, 24-38, 39-41, 42-44, en 45.

- Die eerste paragraaf of proloog (vers 1-6) en die laaste paragraaf of epiloog vorm nie 'n deel van die vertelteks nie. Dit omarm die eintlike vertelteks (vers 7-44). 


\subsubsection{Fokalisasie}

\subsubsection{Eksterne en interne fokalisasie}

In Psalm 105 word daar hoofsaaklik van eksterne fokalisasie gebruik gemaak. Daar word deur die verteller op gebeure en karakters gefokus. Dit is slegs in die geval van verse 11 en 15 waar interne fokalisasie voorkom. Dit vind plaas wanneer daar deur een van die karakters (Jahwe) op 'n ander karakter (Israel) gefokus word.

Die oorwegend eksterne fokalisasie in Psalm 105 kom op die volgende vlakke na vore:

perseptueel: die verteller het 'n 'panoramiese uitsig oor al die gebeure in die verhaal' (vgl Potgieter 1988:95);

psigologies: die verteller het insig in die emosies van die karakters (vers 38);

ideologies: die ideologie van die verteller is die 'gesaghebbende ideologie waaraan die ander ideologieë ondergeskik is' (Potgieter 1988:97).

\subsubsection{Die verteller se ideologiese perspektief}

In die woorde van Van Aarde (1982:61) kan die vertellersperspektief op die ideologiese vlak "bestempel word as die "idee" wat die grondliggende prinsiep uitmaak waarvolgens die vertelling en sy vertelelemente gekonstitueer is'. In die geval van Psalm 105 kan ons sê dat die besit van die land Kanaän deur die volk Israel op grond van God se belofte hierdie grondliggende prinsiep uitmaak. Die verteller se ideologiese perspektief het dus 'n ruimtelike dimensie. Daar word in die besonder daarop gefokus deurdat vers 11 in die direkte rede gestel is.

\subsection{Storie}

\subsection{Tyd}

\subsubsection{Chronologiese opeenvolging van gebeure}

Brink (1987:54) sê: 'Dit is immers danksy die aaneenskakeling van afsonderlike gebeurtenisse in kleiner en groter reekse dat 'n storie uit die vertelteks ontvou.' Hierdie 'reekse' sien in die geval van Psalm 105 soos volg daar uit:

* God bring sy verbond met Israel tot stand (vers 7-11);

- God beskerm sy volk persoonlik toe hulle nog min en sonder land was (vers 12 15 );

- God voorsien aan sy volk in die tyd van 'n wêreldwye hongersnood (vers 16-23);

- God beskerm sy volk teen die bedreiging van die Egiptenare (vers 24-38);

- God beskerm sy volk teen die gevare van die woestyn (vers 39-41); 
- God het sy verbond gestand gedoen en aan sy volk 'n eie land gegee (vers 4244).

\subsubsection{Kousale verband}

Die plot van ' $n$ vertelling is nie bloot 'n optelsom van die reekse in die vertelling nie. Dit gaan hier om die verhouding waarin hierdie reekse tot mekaar staan en die wyse waarop hulle saam funksioneer. 'Chronologie op sigself is egter nie genoeg om 'n gebeurelyn te konstitueer nie. Gewoonlik gaan dit gepaard met die leser se ondervinding van en behoefte aan 'n logiese opeenvolging' (Brink 1987:60). Die kousale verband waarin die verskillende reekse tot mekaar staan, word volgens die drie Aristoteliaanse fases verdeel in die begin, middelstuk en slot. Hiervolgens kan die reekse in Psalm 105 só ingedeel word:

vers 7-11: begin;

vers 12-41: middelstuk;

vers 42-44: slot.

In die begin word die instelling en inhoud van God se verbond met Israel beskryf. In hierdie beskrywing word baie sterk beklemtoon dat Jahwe sy beloftes altyd nakom. Die funksie van die begin (vers 7-11) binne die narratiewe opbou van die psalm is dus om die verwagting by die leser te wek dat die vervulling van die landsbelofte vasstaan. Dit is opvallend dat die tweeledige verbondsbelofte van ' $n$ land sowel as 'n nageslag nie in die psalm voorkom nie. Dit is slegs die belofte van 'n eie land wat hier ter sprake is.

In die middelstuk ontplooi die verhaal en word bogenoemde verwagting verder uitgewerk. Die uitkoms van God se belofte word telkens bedreig, maar God voorsien elke keer 'n oplossing. Die middelstuk bestaan uit vier reekse waarin God se dade ter beskerming van sy volk bespreek word. Hierdie vier reekse het parallelle handelingslyne:

$\begin{array}{llll}\text { REEKS } & \text { BEDREIGING } & \text { OPLOSSING } & \text { AFLOOP } \\ 12-15 & \text { verdrukking } & \text { God gryp self in } & \text { (volk gehandhaaf) } \\ 16-23 & \text { hongersnood } & \text { Josef } & \text { Jakob na Egipte } \\ 24-38 & \text { onderdrukking } & \text { Moses en Aäron } & \text { volk word uitgelei } \\ 39-41 & \text { woestyn } & \text { natuurverskynsels } & \text { (volk trek voort). }\end{array}$

Brink (1987:57) wys op Bremond se indeling van die drie fases in die dinamiese handeling waardeur' $n$ teks ontstaan, naamlik: 
- die virtualiteit van 'n gebeurtenis, dit wil se die aanbied van 'n stel omstandighede wat lei tot verandering,

- die voltrekking of aktualisering van die gebeurtenis self, en

- die resultaat of afsluiting van die proses.

Brink (1987:57) sê ook dat hierdie patroon nie net betrekking het op die verhaal as geheel nie, maar op al die prosesse binne daardie verhaal wat gebeurereekse laat ontstaan. Dit is duidelik dat die vier reekse van die middelstuk van Psalm 105 volgens bogenoemde indeling baie goed in hierdie skema van Bremond inpas.

Elkeen van hierdie vier reekse vorm 'n verhaal in die kleine met 'n eie plot. Elkeen is ook in 'n mindere of meerdere mate 'n opsomming van 'n sekere tydperk in die geskiedenis van Israel. Daarom is daar in elkeen sprake van die vertraging van die lineêre tydsverloop. Vers 12-15 staan effens los van die res en dit word bevestig deur die ellips tussen vers 15 en 16 . Die laaste drie reekse van die middelstuk staan in 'n chronologies-kousale verband tot mekaar. Josef se teenwoordigheid in Egipte maak dit vir Jakob moontlik om hom daar te vestig. Dit gee weer aanleiding tot Israel se verdrukking deur die Egiptenare. Die verdrukking lei weer tot die trek na die woestyn.

\subsubsection{Verteltyd en vertelde tyd}

Wat die verteltyd betref, bestaan die psalm uit vyf en veertig verse en neem dit ongeveer vier tot vyf minute om dit deur te lees.

Uit die verhouding 'verteltyd' tot 'vertelde tyd' blyk dat die tydperk van Israel se verblyf in Egipte voorop gestel word en die meeste gewig dra.

Die gebeure in vers 12-15 word nie nader bepaal nie en is waarskynlik bedoel as die samevatting van 'n bepaalde era in die geskiedenis van Israel.

Die gedeelte oor Josef in Egipte (vers 16-23) is 'n greep uit die lewe van 'n individu maar dit word geïnterpreteer as God se voorsiening aan die hele Israel. Die lineêre tydsverloop word vertraag en daar word gefokus op die lewe van een persoon. Die gedeelte kan beskou word as 'n opsomming van die geskiedenis van Josef in Egipte aangesien heelwat besonderhede ontbreek. Deur die tegniek van vertraging word dramaties klem gele op God se soewereine mag. Josef word nie dadelik in die paleis aangestel nie maar eers in die gevangenis gegooi sodat dit wil voorkom asof God se oplossing nie gaan werk nie. Die leser is egter bewus daarvan dat Josef God se 'gestuurde' is (vers 17).

Die gedeelte oor Israel in Egipte (vers 24-38) is meer beskrywend van aard. In dié reeks val die fokus op die verskillende plae wat God oor die land gestuur het. God se dade word beklemtoon en daarom speel die lineêre tydsverloop nie 'n groot 
rol nie. Ook hierdie gedeelte kan as 'n opsomming beskou word waarin die fokus val op die plae as God se magtige dade. Aanvanklik lyk dit asof die plae wat God stuur, geen indruk op die Egiptenare maak nie (vers 28). Namate die plae vorder, word die Egiptenare se gesindheid egter dramaties oorwoeker deur God se almag.

Die beskrywing van Israel se omswerwinge in die woestyn (vers 39-41) is baie oorsigtelik. Dit bevat slegs enkele grepe uit die tydperk van die woestynverblyf en fokus op God se fisiese versorging van sy volk.

In die geheel beskou is die hele middelstuk (vers $12-41$ ) 'n vertelling waarin die magtige dade van God in herinnering geroep word. Die begin (vers 7-12) funksioneer prospektief aangesien dit die belofte bevat en die verwagting van die vervulling daarvan wek. Die slot (vers 42-44) kan as 'n konklusie of kommentaar beskryf word.

\subsubsection{Frekwensie}

Met 'frekwensie' word bedoel die verhouding tussen die aantal kere wat 'n gebeure in die storie plaasvind tot die aantal kere wat dit in die teks vertel word. Potgieter (1988:57) sê die volgende oor repetisie in die Ou Testament: 'Repetisie is...nie 'n blote konvensie nie, maar word funksioneel ingespan om op 'n beperkte of omvang. ryke wyse elemente te herhaal om bepaalde effekte te bereik. Die funksie van repetisie en ook ander narratiewe konvensies is dus kommunikatief van aard.' In aansluiting by Potgieter se ondersoek na repetisie in die Jonaverhaal kan die voorkoms daarvan in Psalm 105 soos volg beskryf word:

- Clifford (1979) het oortuigend aangetoon dat die herhaling van 'Leitwörter'

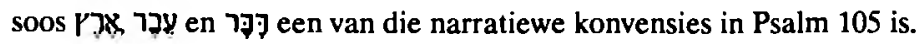

- Daar is reeds gewys op die parallelle handelingslyne van die vier reekse wat deel vorm van die middelstuk (vers 12-41), naamlik die bedreiging van die belofte, die voorsiening van 'n oplossing en die afloop van die gebeure.

- In die reeks wat handel oor Josef in Egipte (vers 16-23), het ons 'n voorbeeld van wat Alter (1981) sou beskryf as 'n 'type-scene', naamlik dié van die sogenaamde wise courtier (vgl Lindeque 1985:15). Josef word voorgestel as die Israeliet wat aan die hof van 'n vreemde koning daarin slaag om 'n hoë posisie in die koning se hofhouding in te neem.

Die funksie van bogenoemde repetisie soos wat dit in Psalm 105 voorkom, is dat daarmee klem gelê word op die sekerheid van die vervulling van God se belofte. 


\subsection{Karakterisering}

Brink (1987:67) se uitgangspunt is: " $[\mathrm{O}] \mathrm{m}$ "karakter" te beskou as iets wat ontstaan uit - en bestaan by - die wisselwerking tussen al drie die wêrelde van 'n verhaal [storie, vertelteks, vertelproses], en tussen al die gegewens, impulse, elemente of aspekte binne daardie hele kompleks.' Daar moet inderdaad gewaak word teen 'n versnippering en oormatige benoeming van die elemente van ' $n$ verhaal. Tog is daar voordeel daarin om die karakters in 'n verhaal tot ' $n$ mate te abstraheer. Dit stel die leser juis in staat om die verhoudinge tussen karakters onderling en die verband tussen die karakters, tyd en ruimte in te sien.

\subsubsection{Funksionele rolle}

In die eerste plek is dit belangrik om te let op die funksionele rol wat elk van die karakters in die vertelling vervul (vgl Breytenbach 1984:2):

- In Psalm 105 is God die protagonis, want dit is deur sy optrede, woorde en houding wat die vertelling ontwikkel en momentum kry.

- Die antagonis in ' $n$ vertelling dwarsboom gewoonlik die protagonis se sending. In Psalm 105 funksioneer die vreemde konings (vers 14) en die Egiptenare (vers 25 ) as antagoniste. Die antagonis in Psalm 105 het veral 'n ruimtelike dimensie. Die ruimte waarbinne die volk hulle telkens bevind, bring elke keer opnuut ' $n$ nuwe bedreiging vir die uitkoms van God se belofte mee. Hierdie aangeleentheid word later breedvoerig bespreek.

- Die objek van verwesenliking of sending waarom dit in die Psalm gaan, is die vervulling van die belofte van 'n eie land.

* Josef, Moses en Aäron funksioneer as helpers om die protagonis se sending te verwesenlik. God gebruik ook natuurverskynsels, soos byvoorbeeld die wolke (vers 39) om Hom te help.

\subsubsection{Simplekse en komplekse karakters}

Die belangrike rol wat God in die vertelling van Psalm 105 vervul, word beklemtoon deur die feit dat God die onderwerp in die oorgrote meerderheid van die vertelde gebeure is. God is dus die karakter in die vertelling wat sorg vir die vloei van die aksie. Sy optrede en dade word oor en oor beklemtoon. Dit is interessant dat God nie alleen sy volk beskerm nie, maar dat Hy self verantwoordelik is vir die bedreigings wat oor hulle kom (vgl vers 16,25$)$. Hierteenoor vervul die volk Israel 'n totaal passiewe rol. Hulle algehele afhanklikheid van God se optrede word beklemtoon. Ons sou dus kon sê dat in hierdie verhaal God 'n komplekse of ronde karakter is, terwyl die volk Israel 'n simplekse of plat karakter is. 


\subsubsection{Naamgewing}

In die proses om aan 'n karakter 'n 'vaste entiteit te gee', is die eienaam van 'n karakter in 'n teks reeds 'n hulpmiddel' (Brink 1987:71). In Psalm 105 word daar reeds in vers 7 na die protagonis verwys as Jahwe en word daar besondere klem op die eienaam van Israel se God geplaas deur die gebruik van die persoonlike voornaamwoord $x$. הie naam Jahwe word in die besonder verbind met Israel se God as die Verbondsgod (vgl Eks 3:13-16). Die verwysings na Abraham, Isak en Jakob (vers 9,10 ) is betekenisvol aangesien hulle die tradisionele stamvaders van Israel was aan wie God die aanvanklike belofte van 'n eie land gemaak het. Ander verwysings na eiename in Psalm 105 is: Israel (vers 10, 23, 38), Josef (vers 17, 22) Egiptenare (vers 25, 27, 35, 38), Moses (vers 26) en Aäron (vers 26).

"n Karakter begin as 'n "oop ruimte" in die teks, benoem deur 'n naam. Daarvandaan word daar algaande, op 'n verskeidenheid van maniere eienskappe, attribute ens in- en aangevul...' (Brink 1987:74). Die besondere verhouding waarin die volk tot Jahwe staan, word op verskillende maniere in Psalm 105 tot uitdrukking ge-

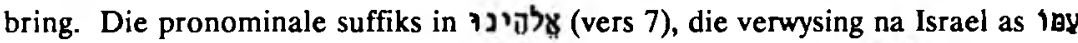

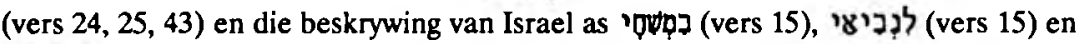
(vers 43) dui alles op die besondere verhouding waarin Israel tot Jahwe staan.

Ten slotte is daar die interessante ooreenkoms tussen:

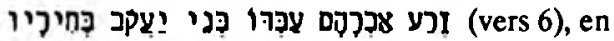

(vers 26).

Die outeur bring hier die belofte en die vervulling daarvan op ' $n$ baie subtiele wyse by mekaar uit deur middel van die parallel tussen Abraham en Jakob aan die een kant, en Moses en Aăron aan die ander kant.

Indirekte karakterisering is te vinde in die verandering wat by die Egiptenare intree. Aanvanklik het hulle die Israeliete onderdruk en gehaat (vers 25). Na God se ingryping was die Egiptenare egter bang vir die Israeliete en bly dat hulle vertrek het (vers 38).

\subsubsection{Informasiebronne}

Volgens Brink (1987:76) se onderskeid tussen eksplisiete en implisiete informasie is daar in Psalm 105 voorbeelde van eksplisiete sowel as implisiete informasie oor die karakters. Eksplisiete informasie oor die karakters in Psalm 105 word hoofsaaklik deur die verteller self verskaf. Jahwe se versorging en beskerming van sy volk is weer implisiete informasie wat afgelei kan word uit Jahwe se optrede. Dit werp lig op die verhouding tussen Jahwe en Israel. 


\subsubsection{Ruimte}

Ruimte is een van die elemente op die vlak van die 'storie' in ' $n$ verhaal en behoort derhalwe hier bespreek te word. Aangesien ruimte egter so 'n besondere funksie in Psalm 105 vervul, word dit as 'n afsonderlike afdeling later in hierdie artikel behandel.

\subsection{Vertelproses}

Brink (1987:150) vat die verskillende vertelhoudinge in 'n verhaal met die volgende skema van Chatman saam:

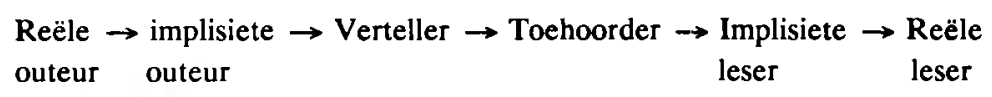

\subsubsection{Die rečle outeur en reële leser}

Die reële outeur van Psalm 105 kan nie meer met enige sekerheid bepaal word nie. Dit het geen sin om binne hierdie artikel al die moontlike tradisies en hipoteses te ondersoek nie. Dit is voldoende om te sê dat die reële outeur onbekend is.

Om die reële leser te bepaal is net so 'n onbegonne taak. Weens 'n gebrek aan inligting is dit vandag onmoontlik om met enige sekerheid te kan sê wie die oorspronklike leser(s) van die psalm was. Ons moet in gedagte hou dat die psalm as 'n lied gesing is en dus waarskynlik in 'n stadium in die kultus van Israel gefunksioneer het (Weiser 1962:673). In elk geval het 'n wye verskeidenheid mense deur die loop van eeue die psalm gelees.

\subsubsection{Verteller en toehoorder}

In Brink (1987:151) se terme het ons in Psalm 105 met 'n 'eksterne verteller' te doen. Dit wil sê die verteller staan buite die storiewêreld en maak van 'n derdepersoonsvertelling gebruik. Deur die pronominale suffiks in (vers 7) word nabyheid van die verteller by die vertelde gebeure geskep sodat die verteller in Genette se terme as 'homodiëgeties' beskryf kan word (vgl Brink 1987:152). Dieselfde geld ook vir die toehoorder, aangesien die verteller en die persoon tot wie hy hom rig, op 'n gelyke vlak in die vertelling van Psalm 105 funksioneer.

\subsubsection{Implisiete outeur en implisiete leser}

Volgens Brink (1987:148) is die implisiete outeur "n vormgewende, selfs vertolkende instansie agter die verteller wat in mindere of meerdere mate in die teks self fungeer en dus ook by die kommunikasieproses betrek word....' Daar bestaan 'n noue band tussen die implisiete outeur en die implisiete leser. Die twee komplementeer 
mekaar. Die implisiete leser is "die instansie wat uit die "skematiseringe" van 'n wêreld soos dit in die vertelteks aangebied word, "oop plekke" invul volgens die "instruksies" van die teks, ten einde die teks te kan konkretiseer...' (Brink 1987:149). In die ondersoek na die implisiete outeur en leser gaan dit dus om die verhouding tussen die vertelde wêreld en die werklike wêreld. Van Aarde (1984:11) formuleer dit soos volg: 'Dit is die studie van die implisiete/geïdealiseerde leser en sy "ideologiese perspektiewe" ingebed in 'n bepaalde temporele, sosiologiese, kultuurhistoriese, godsdienstige en aardrykskundige bedding.'

In die lig van bogenoemde kan die volgende oor die implisiete outeur en leser van Psalm 105 gesê word:

- Eerstens word die implisiete lesers in die proloog (vers 1-6) eksplisiet genoem: '...julle, nageslag van Abraham sy dienaar, nakomelinge van Jakob vir wie Hy uitverkies het' (NAB). Die implisiete lesers kan dus breedweg gesien word as lede van die volk Israel. Maar wat is die omstandighede waarin hulle leef?

* Uit die manier waarop die implisiete outeur aan die teks 'vorm gee' of 'skematiseer', kan ons in die tweede plek aflei dat die implisiete lesers waarskynlik in 'n soortgelyke situasie verkeer het as dié waarin die volk Israel volgens die vertelling verkeer het. Dit wil sê, die implisiete lesers bevind hulle waarskynlik in 'n situasie waar die uitkoms van God se belofte van 'n eie land aan die 'nageslag van Abraham' opnuut bedreig word. Ons kan dus met Clifford (1979:427) saamstem as hy sê: "[The poem] retells those traditions which underscore the fidelity of God to the people at times when they did not in fact possess the land...The psalm invites Israel to praise and seek the God who promised the land to them, regardless of whether they possess the land in fact.' Die belangrike rol wat ruimte in die psalm speel, met spesiale verwysing na die funksie van Yh, bevestig die vermoede dat die implisiete lesers hulle in 'n situasie bevind waar hulle nie in besit van die land is nie.

* 'n Mens kan ten slotte nie net aflei dat die implisiete lesers nie die land besit nie, maar ook dat hulle hulle waarskynlik binne bedreigende en gevaarlike omstandighede bevind. Dit is veral die ruimte waarbinne hulle hulle bevind wat vir hulle ' $n$ bedreiging inhou.

\section{DIE VOORKOMS EN FUNKSIE VAN RUIMTE IN PSALM 105}

\subsection{Ruimte as vertelkundige dimensie}

Brink (1987:108) is van mening dat 'alles wat in die vertelteks gebruik word om...'n situasie te konstitueer waarbinne "iets met iemand gebeur", tot die konsep van narratiewe ruimte behoort. Dus: nie net die plek of omgewing...waar die insidente 
plaasvind of waarin die karakters optree nie, maar die hele "narratiewe klimaat" daar rondom'. Hy onderskei dan tussen 'vertellersruimte' (dws die ruimte waarbinne, of van waaruit die verteller sy vertelteks sit en voortbring), 'vertelruimte' (dws sintaktiese en semantiese patrone van die taal) en 'vertelde ruimte' (dws die ruimte van die storie wat in die teks deur die verteller vertel word).

Van Eck (1986) het reeds op die funksie van ruimte in 'n vertelling gewys. Ten einde die besondere funksie daarvan in die vertelling in Psalm 105 aan te toon, word die bespreking van ruimte in hierdie artikel beperk tot die vertelde ruimte. Volgens Brink (1987:118-122) beweeg die ruimte in 'n vertelling op 'n glyskaal tussen konkrete ruimte en abstrakte ruimte. 'Konkrete ruimte' verwys na ruimte in terme van 'plek' of 'omgewing'. Met 'abstrakte ruimte' word die gevoelswaarde wat aan 'n sekere plek geheg word, bedoel. Dit word bepaal deur sosiale, politieke, ekonomiese, historiese, ideologiese, religieuse, filosofiese en ander dimensies van menslike ervaring wat aan 'n plek gekoppel word.

\subsection{Vertelde ruimte in Psalm 105}

\subsubsection{Ruimte as objek van verwesenliking}

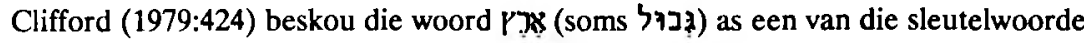
in die psalm. Dit kom voor in verse 7, 11, 12 (in die voornaamwoord), 16, 23, 27, 30, $31,32,33,35,36$ en 44 . Vers 11 bevat die inhoud van die belofte in kompakte vorm: 'Ek gee die land Kanaän vir jou as grondgebied en eiendom' (NAB). Die ongewone woordorde in die sin met 7 לan die begin, plaas besondere klem op die ontvanger van die belofte. Dit kan moontlik vertaal word met 'Vir jou, en niemand anders nie

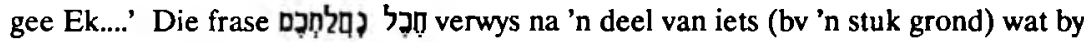
wyse van afmeting met ' $n$ maatlyn aan iemand as besitting toegeken is (vgl Ps 16:6). Die woord נגלְל verwys onder andere na 'n permanente of vaste besitting. 'Im erweiterten Gebrauch kann נִלְל den Erbbesitz allgemein...sowie einen dauerenden Besitzanspruch an unterworfenen Personen oder Völkern bezeichnen' (Jenni \& Westermann 1978:55). Die derde persoon enkelvoud vroulike voornaamwoord aan die einde van vers 12 verwys terug na Israeliete by 'n vorige geleentheid in die land Kanaän was, alhoewel hulle nie die land besit het nie.

In vers 12 word daar na die Israeliete se verblyf in Egipte as Dיר verwys. Volgens Jenni \& Westermann (1978:409) onderskei die ר hom van die uitlander in die algemeen daarin dat hy 'n 'vreemdeling' is wat hom vir ' $n$ bepaalde tyd in die land gevestig het en so 'n besondere status bekom het. Die 7 (hetsy enkeling of groep) is iemand wat sy vaderland weens politieke, ekonomiese of ander omstandighede verlaat het om in ' $n$ ander gemeenskap ' $n$ heenkome te vind. 'n Baie belangrike 
eienskap van die 73 was dat hy geen grond besit het nie. So is die Leviete wat nie

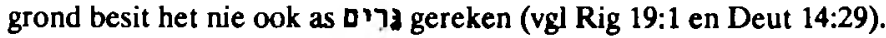

Vers 44 funksioneer as die uiteindelike vervulling van die belofte en verwys terug na vers 11 . Die volk Israel het geen reg of aanspraak op die land nie. God 'gee' (1 1 ?!) die land aan hulle en Israel ontvang dit as 'n erfdeel (7'?'). Die belofte van 'n eie land vir die volk Israel loop soos 'n goue draad deur die hele psalm en kom uiteindelik in vers 44 tot 'n hoogtepunt waar hierdie belofte in vervulling gaan.

\subsubsection{Ruimte as bedreiging vir die uitkoms van die belofte}

Soos reeds vroeër aangedui, is daar in die vier reekse van die middelstuk parallelle handelingslyne te bespeur, naamlik die vervulling van die belofte wat bedreig word, God se voorsiening van 'n oplossing en die afloop. In elk van die vier reekse is die bedreiging vir die vervulling van die belofte ruimtelik van aard.

In vers $12-15$ is dit juis die gebrek aan bewoningsruimte wat 'n bedreiging vir die voortbestaan van die volk inhou. Hulle is nie in besit van die land nie en swerf rond van die gebied van een volk na dié van 'n ander. Daarby is hulle nog klein in getal ook. Dit maak die gevaar van opname in of verslawing deur een van die volke wat wel van die grond besit, soveel groter.

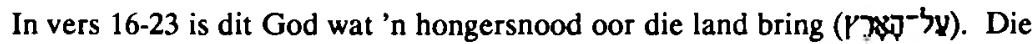
ruimte waarbinne die volk hulle bevind, word dus 'n bedreiging vir hulle voortbestaan, maar God maak voorsiening vir die uitkoms binne 'n ander ruimte, naamlik Egipte. Die feit dat die volk Israel die land Kanaän moet verlaat, wek spanning. Dit bring die vraag na vore of die belofte van die land Kanaän as Israel se eie besitting nog steeds van $\mathbf{k r a g}$ is noudat hulle die land moet verlaat.

Egipte (vers 24-38) wat aanvanklik as die uitkoms vir die bedreiging van die hongersnood funksioneer, word egter gou weer die ruimte waarbinne die voortbestaan van die volk bedreig word. In Egipte groei die volk in getal sodat hulle naderhand vir die Egiptenare 'n bedreiging word en deur hulle onderdruk word. In vers 37 word vertel hoe God weer self sy volk uit hierdie ruimte lei.

Dit wil voorkom asof die moontlikheid dat die belofte in vervulling sal gaan, al hoe skraler word. Die ruimte wat die volk nou betree, lyk nog hopeloser. Dit is die onherbergsame woestyn, vol fisiese gevare. In die woestyn is daar byvoorbeeld die gevaar van hitte, uitputting, verdwaal in die nag en gebrek aan kos en water. Al hierdie gevare word egter oortref deur God se magtige dade. God maak van natuurverskynsels gebruik om sy volk teen hierdie bedreigende, gevaarlike ruimte te beskerm. Hy bedek hulle met 'n wolklaag om hulle teen die versengende hitte van die son te beskerm, Hy lei hulle in die nag deur middel van 'n vuurgloed sodat hulle 
nie verdwaal nie, Hy stuur die kwartels en brood uit die hemel vir hulle om te eet en Hy laat vir hulle water uit 'n rots kom sodat hulle kan drink.

\subsection{Egipte as ruimte}

Te oordeel aan die aantal verse wat verwys na gebeure wat in Egipte afspeel, is Egipte 'n baie belangrike ruimte in die psalm. Meer as die helfte van die vertelling (vers 16-38) speel af teen Egipte as agtergrond. Terwyl daar in die res van die wêreld hongersnood heers, is daar in Egipte kos beskikbaar.

In verse 23 en 27 word na Egipte verwys as die Ou Testament word hierdie uitdrukking dikwels in verband met Egipte gebruik. Dit geskied na aanleiding van Genesis 10:6 waar Egipte as deel van die nageslag van Gam, die seun van Noag beskou word. Dit wil voorkom asof daar nie een of ander gevoelswaarde aan die naam Gam gekoppel moet word nie. Dit is bloot net 'n poëtiese sinoniem vir Egipte.

Clifford (1979:425) wys op die chiasme in vers 25-29 wat gevorm word deur die

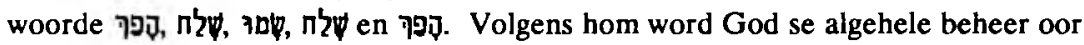
Egipte hiermee uitgedruk. Hy wys ook op die kontras tussen Egipte en die woestyn. Deur sy woord stuur God vernietigende plae en peste oor Egipte, maar wanneer Israel in die woestyn vra om kos, stuur Hy vir hulle kos uit die hemel. Die volgorde van die plae dra verder tot hierdie kontras by. In die plek van die duisternis wat God oor Egipte as 'n plaag gestuur het, gee hy vir Israel 'n vuurkolom om die duisternis in die woestyn te verdryf.

Ceresco (1983:34) wys op die ironie in die gedeelte oor Egipte. Eerstens is daar die dubbele betekenis van עִ עִ naamlik slaaf (van mense) en dienskeg (van God) in vers 17 en 26. Verder kan daar gelet word op die feit dat Josef Egipte inkom met

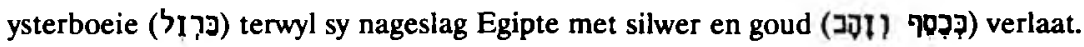
'[T]he author invites us to look beyond what appears to be a slave stumbling under the burden of his chains and see that in fact that slave is foreshadowing a future that Providence was planning - the despoilment of the Egyptians at the Exodus' (Ceresko 1983:35).

Die funksie van hierdie kontras tussen Egipte en die woestyn dien daartoe om aan te toon dat God situasies kan omkeer. Die suggestie is klaarblyklik dat hulle wat landloos is, landbesitters sal word. 


\subsubsection{Universalisme}

In Psalm 105 kry ons die volgende aanduidings van 'n universalistiese tendens:

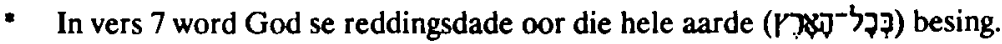

- Die feit dat God mag het oor die hele aarde word in die psalm op verskeie plekke verwoord. Ceresco (1983:44) stel dit so:

The importance of 'land' in the psalm is thus obvious. But there is an additional note of irony. Again and again reference is made to 'the land of Canaan' [wv 11, 16 'eres kena'an], 'the land of Ham' [w 23, 27 'eres bam], 'their land' [w 30, 32, 35, 36 'arsam], and 'the lands of the nations' [v 44 'ars 0 t goyim]. Although these lands are said to belong to the Canaanites [w 11, 16, 44] and Egyptians [w 23, 27, 30, 32, 35, 36 ] in the background lies the very first use of 'eres in $v 7$ serving as a reminder that in fact 'the whole earth' [kolha'ares] i.e. all the lands, belong to Israel's God. The nations hold their lands only by concession from him, and he is free to promise and ultimately to present the land of Canaan to Abraham's descendants.

Bogenoemde universalistiese tendens onderbou een van die hoofsake in die psalm naamlik dat Jahwe se mag hom uitstrek oor die hele aarde.

\section{KONKLUSIE}

4.1 Die bostaande ondersoek het aangetoon dat ' $n$ vertelkundige ontleding wel met vrug op Psalm 105 toegepas kan word. Alhoewel so 'n ontleding nie noodwendig nuwe betekenis of interpretasiemoontlikhede meebring nie, is dit tog 'n verfrissende nuwe metode om ou waarhede opnuut te ontdek. 'n Vertelkundige ontleding is nie noodwendig 'n 'beter' metode om 'n teks mee te ontleed as enige ander metode nie. Dit is maar net een metode te midde van 'n veelheid van metodes. Tog is dit so dat ' $n$ vertelkundige ondersoek van ' $n$ teks nuwe lig op die teks werp omdat die teks vanuit ' $n$ ander hoek benader word. Die besondere rol wat ruimte in Psalm 105 speel, word baie effektief deur 'n vertelkundige ontleding aan die lig gebring.

4.2 Op grond van die vertelkundige ontleding kan die volgende teologiese tendense ten opsigte van Psalm 105 gestel word:

4.2.1 In die verhouding tussen God en sy volk is God die een wat aktief is en die een wat die inisiatief neem. Dit kom duidelik na vore uit die wyse waarop God as karakter in die vertelling geskets word. 
4.2.2 In hierdie verhouding tussen God en sy volk is God altyd getrou, ongeag die wisseling in die omstandighede van die volk. Elke nuwe aardse omstandigheid of omgewing bring vir die volk nuwe bedreiginge, maar God is in staat om elke nuwe bedreiging die hoof te bied en sy volk te beskerm. Hierdie feit word in Psalm 105 beklemtoon deur die voortdurende wisseling in ruimte en die bedreiging wat elke nuwe ruimte meebring. Tog is nie een van hierdie 'ruimtelike bedreigings' in staat om te verhinder dat God se aanvanklike belofte realiseer nie.

4.2.3 God moet geprys en gedien word ongeag 'n mens se aardse omstandighede. Die volk word opgeroep om God te loof op grond van sy magtige dade in die verlede en nie op grond van die volk se huidige omstandighede nie. Terselfdertyd impliseer die oproep ook die hoop en verwagting dat God weer in die toekoms sy belofte sal laat realiseer. Soos wat daar in die verlede baie bedreiginge was vir die vervulling van God se belofte, so word verwag dat God weer in staat sal wees om die huidige bedreiging die hoof te bied.

4.3 Wat die ontstaanstyd en -plek van die psalm betref, het Clifford (1979) reeds oortuigend aangevoer dat die psalm waarskynlik in die sesde eeu $v \mathrm{C}$ sy ontstaan gehad het. Ceresco (1983) bou hierop voort wanneer hy die Babiloniese ballingskap as die waarskynlike ontstaanstyd van die psalm aandui. 'n Vertelkundige ondersoek komplementeer bogenoemde standpunt. Uit die ondersoek na die implisiete outeur en leser het dit geblyk dat die volk hulle waarskynlik ook in 'n situasie bevind waar hulle nie in besit van die land is nie. Die belangrike rol wat ruimte, veral 'die land', in die psalm speel, versterk hierdie vermoede. Die feit dat die ruimte waarbinne die volk Israel hulle bevind, telkens as bedreigend voorgestel word, kan daarop dui dat die psalm moontlik in Babilonië sy oorsprong gehad het. Die swaar klem op die absolute soewereiniteit van Jahwe klop met die teologiese beklemtonings van ander literatuur in die tyd van die Babiloniese ballingskap (vgl Jes 45:7). In die lig hiervan kan dit as 'n waarskynlikheid gestel word dat die eerste reële lesers (of hoorders) van die psalm Israeliete was wat hulle in Babilonië in ballingskap bevind het.

\section{Literatuurverwysings}

Alter, R 1981. The art of Biblical narrative. New York: Basic Books.

Bal, M 1980. De theorie van vertellen en verhalen. Muiderberg: Coutinho.

Breytenbach, A P B 1984. 'n Narratiewe ontleding van Psalm 106. Ongepubliseerde nagraadse seminaargids, Fakulteit Teologie (Afd A), Universiteit van Pretoria.

Brink, A P 1987. Vertelkunde: 'n Inleiding tot die lees van verhalende tekste. Pretoria: Academica. 
Ceresco, A R 1978. Function of chiasmus in Hebrew poetry. $C B Q 40,1-10$.

--- 1983. A poetic analysis of Ps 105, with attention to its use of irony. Biblica 64, 20-46.

Clifford, R J 1979. Style and purpose in Psalm 105. Biblica 60, $420-427$.

Fensham, F C 1981. Neh. 9 and Pss. 105, 106, 135 and 136: Post-exilic historical traditions in poetic form. Joumal of Northwest Semitic Languages 9, 35-51.

Genette, G 1980. Narrative discourse. Oxford: Blackwell.

Hill, A E 1983. Patchwork poetry or reasoned verse? Connective Structure in 1 Chronicles xvi. VT 33, 97-101.

Holm-Nielsen, S 1977. The Exodus traditions in Psalm 105. ASTI 11, 22-30.

Jenni, E J \& Westermann, C 1978. Theologisches Handwönterbuch zum Alten Testament. München: Kaiser.

Lindeque, G C 1985. 'n Vergelykende studie van Genesis 41 en Daniël 2 vanuit 'n narratologiese perspektief. BD Skripsie, Universiteit van Pretoria.

Potgieter, J H 1988. 'n Narratologiese ondersoek van die boek Jona. DD Proefskrif, Universiteit Pretoria.

Prince, G 1982. Narratology: The form and function of narrative. Berlin: Mouton.

Van Aarde, A G 1982. Die vertellersperspektief-analise: 'n Literatuurteoretiese benadering in die eksegese van die evangelies. HTS 38/4, 58-81.

-.- 1984. Eksegese van vertelmateriaal. Ongepubliseerde klasaantekeninge, Fakulteit Teologie (Afd A), Universiteit van Pretoria.

Van Eck, E 1986. Die funksie van ruimte in die narratologie. HTS 42, 339-349.

Weiser, A 1962. The Psalms: A commentary. Londen: SCM. 